\title{
Accounting Information System for Cattle Feed Control to Achieve Feed Consumption Efficiency
}

\section{Rendra Prasetya and A.A. Gde Satia Utama}

Departemen Akuntansi, Universitas Airlangga, Surabaya,Indonesia

\section{Abstract}

Dairy cattle farm of Mr. Djamil, located in the district of Ngantang Malang Regency, is engaged in dairy cattle breeding and produces cows milk. The same as other dairy cows breeders, the rise in the price of cattle feed, commonly called concentrate, is not counterbalanced by the rise in milk price causing the farmers not to get maximum profits. Therefore, the breeders try to make efficient use of the concentrate by creating innovations in combining dairy feed. The development of dairy cattle feed combination is done so that the amount of milk produced by the dairy farmers is not reduced even

Corresponding Author: Rendra Prasetya gde.agung@feb.unair.ac.id

Received: 10 February 2019 Accepted: 14 March 2019 Published: 28 March 2019

Publishing services provided by Knowledge E

(c) Rendra Prasetya and A.A. Gde Satia Utama. This article is distributed under the terms of the Creative Commons

Attribution License, which permits unrestricted use and redistribution provided that the original author and source are credited.

Selection and Peer-review under the responsibility of the ICIEBP Conference Committee. though the concentrate feed amount is minimized. The application of dairy cows feed control using the Management Information System is expected to help dairy farmers to efficiently use concentrate and to combine dairy cattle feed as a substitute for the concentrate. Based on this background, the purpose of this study is to analyze the information system of cattle feed inventory at Mr. Djamil's ranch in Ngantang by using Accounting Information System. This research uses qualitative exploratory approach and performs interviews with Mr. Djamil as a dairy cattle breeder to obtain data. The analysis method of this study is by comparing the cost price of cattle feed and the dairy cows milk selling price. The result of the research indicates that dairy cattle farm of Mr. Djamil utilizes the dairy cows feed combination simply through estimation and this can be recognized since the ranch is not achieving the expected returns.

Keywords: Accounting Information System, Internal Control, Cattle Feed, Management, Information System

\section{Preface}

Through breeding 4.7 million cattle, East Java becomes the highest cattle producing region in Indonesia. This indicates that the development of livestock business is quite advanced and well developed in East Java. One of the dairy cattle farming centers in East Java is in Ngantang sub-district, Malang Regency. Ngantang is one of the 33 sub- 
$\mathrm{km} 2$ or about 4.96 percent of the total area of Malang. (www.ngantang.malangkab.go.id: 2014)

Ngantang has mountain topography so it is suitable for dairy cow milk business because dairy cows are able to adapt well in areas with cold or chilly weather. One of the dairy cattle breeders in Ngantang is Mr. Djamil. Mr. Djamil has 33 dairy cows that can produce 100-200 liters of cows milk each day. Dairy cattle owned by Mr. Djamil present in various ages. In order to maximize the amount of milk produced by the cattle, the combination of cows productivity should be appropriate. Based on a counseling conducted by Agriculture Bureau of Malang Regency, the ideal composition of cattle ownership for each year consists of $40 \%$ to $60 \%$ number of productive cows and $20 \%$ to $30 \%$ number of calves. This composition is very important because it greatly affects the harvest of the cows milk. If the calves are too many, the milk produced will be enormously reduced because some of the milk produced will be given to the calves. In contrary, the number of the parent cattle that is too many will make the breeders have to spend more to buy productive cows for substituting unproductive cows.

The assets of the cattle ranch are the dairy cows owned by the farmers. In accounting, referred as a biological asset, are assets that undergone agricultural practice which is a process in managing biological transformation of plants and animals with the aim of producing goods either for consumption or for further development. Alice Tan (2013) in Singapore, a company that has biological assets needs to record the biological assets with relevant accounting standards and uses fair value in measuring the biological assets value to give more time for the assets owner in making decisions regarding the assets owned. Mulyadi (2001:163), Accounting Information Systems (AIS) of Control can be applied to make the profits generated in line with the returns expected. One way to obtain the expected profit is to conduct an information system of control to the composition of cattle ownership.

Mr. Djamil's ranch purchases the cattle feed from suppliers that located in various places. Presently, cattle feed orders are made only by estimation. There is no accurate accounting and inventory management applied in the calculation of feed consumption. This weakness raises the risk of miscalculation of orders and excessive feeding to the cows each day. Another problem that may arise is the inability of the milk selling price to cover the feed cost every day. A type of feeds that affects the cost of feed is concentrate.

One of the ways to overcome the problem is by improving the internal control of the company so that the operational performance of the farmer in managing the cows feed can be effective and the records quality may be enhanced by integration with technology. The need for accounting records, that are in accordance with the 
standards, is to assist the ranch in preparing inventory report of biological assets through the application of AIS based on Manufacturing Information System. Subsequently, the transactions recording that has been done will be supported by clear authorization and supporting documents to help the collection of accounting report informations and evidences.

\section{Theoretical Bases}

\subsection{Accounting information system of purchase}

The activities of a company to determine appropriate quantity and time to receipt the goods are inventory control management activities (Widjajanto, 2001: 353).

\subsection{Biological assets}

Biological assets are assets that experience agricultural activity which is the process of managing biological transformation of plants and animals to create products for consumption and further processing. Rules concerning biological assets are listed in IAS (International Accounting Standard) 41. Indonesia still uses PSAK which does not specifically regulate accounting for agribusiness ventures.

\subsection{Manufacturing information system}

Manufacturing Information System has three input subsystems and four output subsystems (Mc leod and Schell, 2012:415). The input subsystems consist of accounting information system, industrial engineering subsystem and manufacturing intelligence system.

\subsection{Database management system}

A database is an organized data set that is used to present various applications efficiently and controls unnecessary data excess (Loudon \& Loudon, 2010:240). 


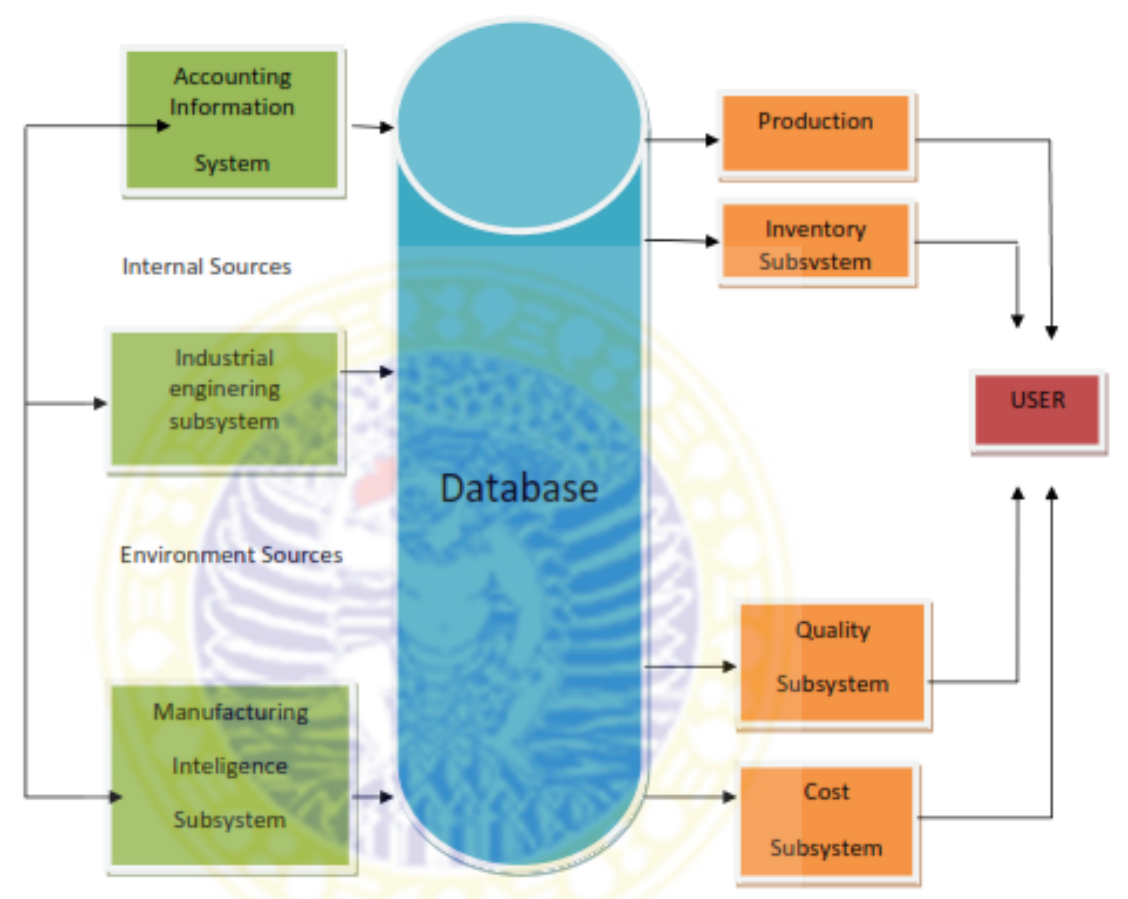

Sumber: Mc Leod dan George Schell. 2012. Management Information System Ninth Edition, New Jersey: Prentice Hall. Halaman: 415

Figure 1: Manufacturing Information System.

\subsection{Internal control}

Internal control system according to Mulyadi (2001:163) includes organizational structure, methods and measures that are coordinated to maintain the wealth of the organization, check the accuracy and reliability of accounting data, boost efficiency and encourage compliance of management policies.

\section{Research Methodology}

The research method used in this research is qualitative approach. Qualitative research is a study that utilizes a natural setting with the intention to interpret a phenomenon that occurs and is done by involving various methods that exist. Qualitative research is a study that uses a naturalistic approach to find and acquire understanding and insight of phenomena in a contextually-specific background (Moleong, 2010:5). This study focuses on the accounting information system of internal control that used by Mr. Djamil as a dairy cattle breeder. Data analysis in this study use three period start from January until Maret 2014. 


\section{Discussions}

\subsection{Overview}

Dairy cattle ranch of Mr. Djamil is a business venture located at Ngantang district of Malang regency that established since 1995. Initially, the owner of the ranch, Mr. Djamil capitalizes five cows that are placed next to a house where he lived and the cows were raised by himself. Mr. Djamil interested in breeding dairy cows since the process of selling the milk in Ngantang is vastly trouble-free. The farmers can sell the milk in Village Unit Cooperative of Sumber Makmur which will market the milk because it collaborates with PT. Nestle in Kejayan, Pasuruan. The location of Village Unit Cooperative of Sumber Makmur is in Ngantang and is very favorable for Mr. Djamil since he does not need to spend too much in transportation costs. On top, the selling price of the milk in there is comparatively profitable which is $\mathrm{Rp} .2,600$ to $\mathrm{Rp} 3,000$ for every liter.

Since the establishment of the ranch in 1995 until 2014, feeding of cattle is solely based on estimation that recorded manually. When the feed stock is expended, the owner will buy from the suppliers and consequently the feed consumption is not measurable. The breeder will experience loss when the cost of the feed is greater than the selling price of the milk. Vice versa, it will benefit the farmer if the cost of the feed is smaller than the selling price of the milk. In the dairy cows farm of Mr. Djamil, the percentage of the productive cattle (milk-producing cows) is smaller than the unproductive ones (non-dairy cows). As a result, the selling price of the milk is not able to cover the daily cost of the feed.

\subsection{Manufacturing information system}

Feed purchase system that is currently used by the Mr. Djamil's ranch is FOB Destination. In this system, the payment will be made at the time the goods received by the breeder. The current composition of the cattle ownership can be seen in Table 3 below:

TABLE 1: The current composition of the cattle owners.

Type of Cattle
Calves
Heifers
Productive Cow
Dry Cattle

\begin{tabular}{|l|}
\hline January \\
\hline $16 \%$ \\
\hline $13 \%$ \\
\hline $48 \%$ \\
\hline $22 \%$ \\
\hline
\end{tabular}

\begin{tabular}{|c|}
\hline February \\
\hline $18 \%$ \\
\hline $12 \%$ \\
\hline $51 \%$ \\
\hline $18 \%$ \\
\hline
\end{tabular}

\begin{tabular}{|l|}
\hline March \\
\hline $27 \%$ \\
$10 \%$ \\
\hline $54 \%$ \\
$10 \%$ \\
\hline
\end{tabular}




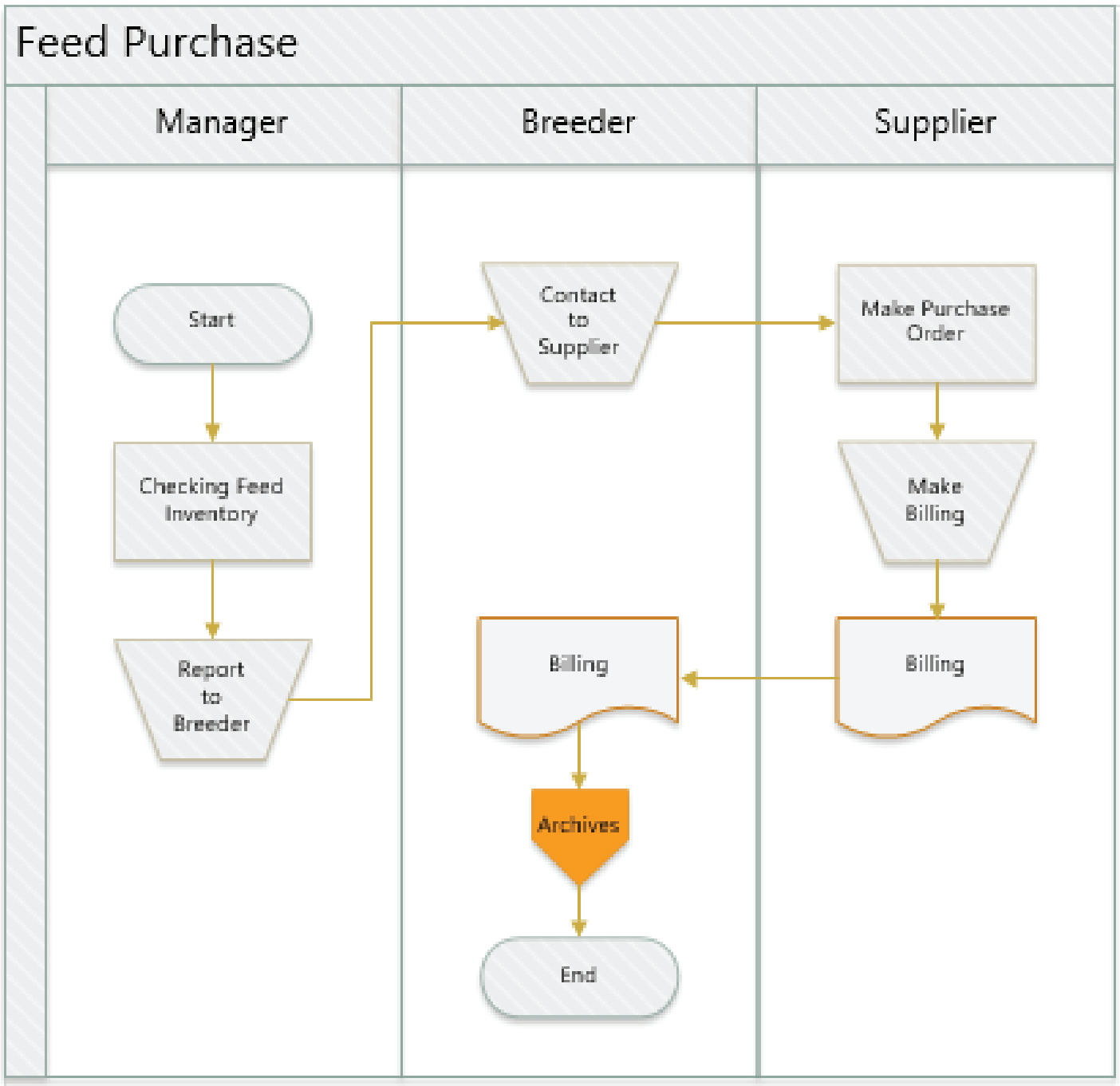

Figure 2: Flowchart of cows feed purchase.

In January 2014, the difference between the cost of the feed and the selling price of the milk was Rp 227,850. For feeding the productive cows, Mr. Djamil's ranch needed $15 \mathrm{~kg}$ of concentrate, $10 \mathrm{~kg}$ of grass, $5 \mathrm{~kg}$ of corn stalks, and $5 \mathrm{~kg}$ of beer dregs. As a result, 205 liters of milk were able to produce. In January, the profit earned was not as much as the farmer expected. The profit was merely Rp 2,000,000 while to further develop the ranch's business, the breeder need to earn a profit of $\mathrm{Rp} 7,000,000$ to $\mathrm{Rp}$ $8,000,000$. The $\mathrm{Rp} 2,000,000$ profit is considered not maximum because selling price of heifers had reached Rp 5,000,000. Moreover, the purchase price of productive cows was $\operatorname{Rp} 10,000,000$.

Income Statement

Mr. Djamil Cattle Feed

In Januari 2014 


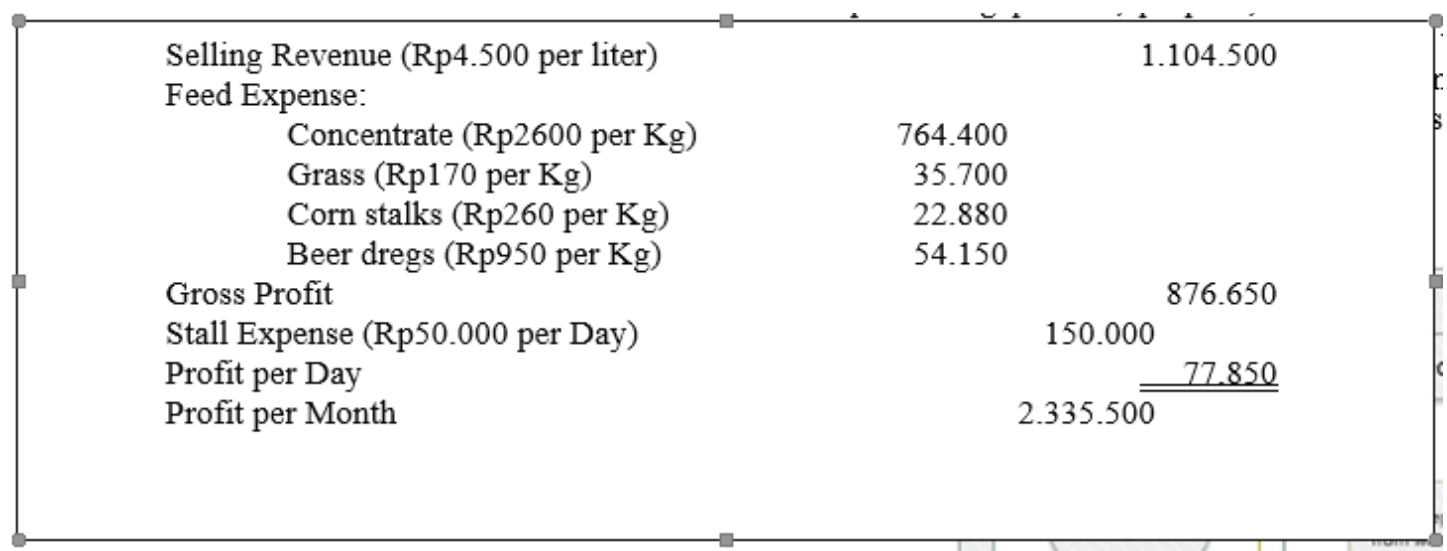

Figure 3: Income Statement.

\subsection{Proposed accounting information system of inventory}

The proposed Manufacturing Information System utilization is to still exercise the same method. Payment is made in cash when the goods received so that the breeder can save his time. It should also be considered that the cattle feed, which is a biological asset, can be damaged within two weeks hence the breeder should not order too much. If the order is too much and the feed has not completely exhausted in two weeks, the cattle feed will be damaged. When the payment is made after the order and the weight of the feed ordered does not match the weight of the feed received, an internal error might arise and the previous payment ought to be confirmed again. In view of that, the feed ordering system through FOB Destination needs to be maintained.

When receiving delivery of the cattle feed from the suppliers, the breeder should request proof of delivery and invoice. The document is required as a supporting document for the financial statements so that the likelihood of the breeder experiencing material loss or risk of fraud can be minimized. Farmer should also consider the use of database of warehouse inventory, feed purchase, and daily milk sales. The database is useful in recording every transaction in a written form and strong enough to collect evidences. By using Manufacturing Information System, Mr. Djamil's ranch can manage the feed inventory. After making the process flow design for the cattle feed inventory purchase transaction on Mr. Djamil's cattle farm based on Manufacturing Information System, the next step is to make Data Flow Diagrams (DFD) and Flowchart to facilitate the understanding. This is due to the fact that this technique is most commonly used in the system. DFD describes the flow of data in the system, starting from the source, processing process, purpose, to data storage. While the flowchart is a symbol that documenting the physical implementation of the system and more focused on the physical design that describes the input, process, and output. 


\section{Feed Purchase}

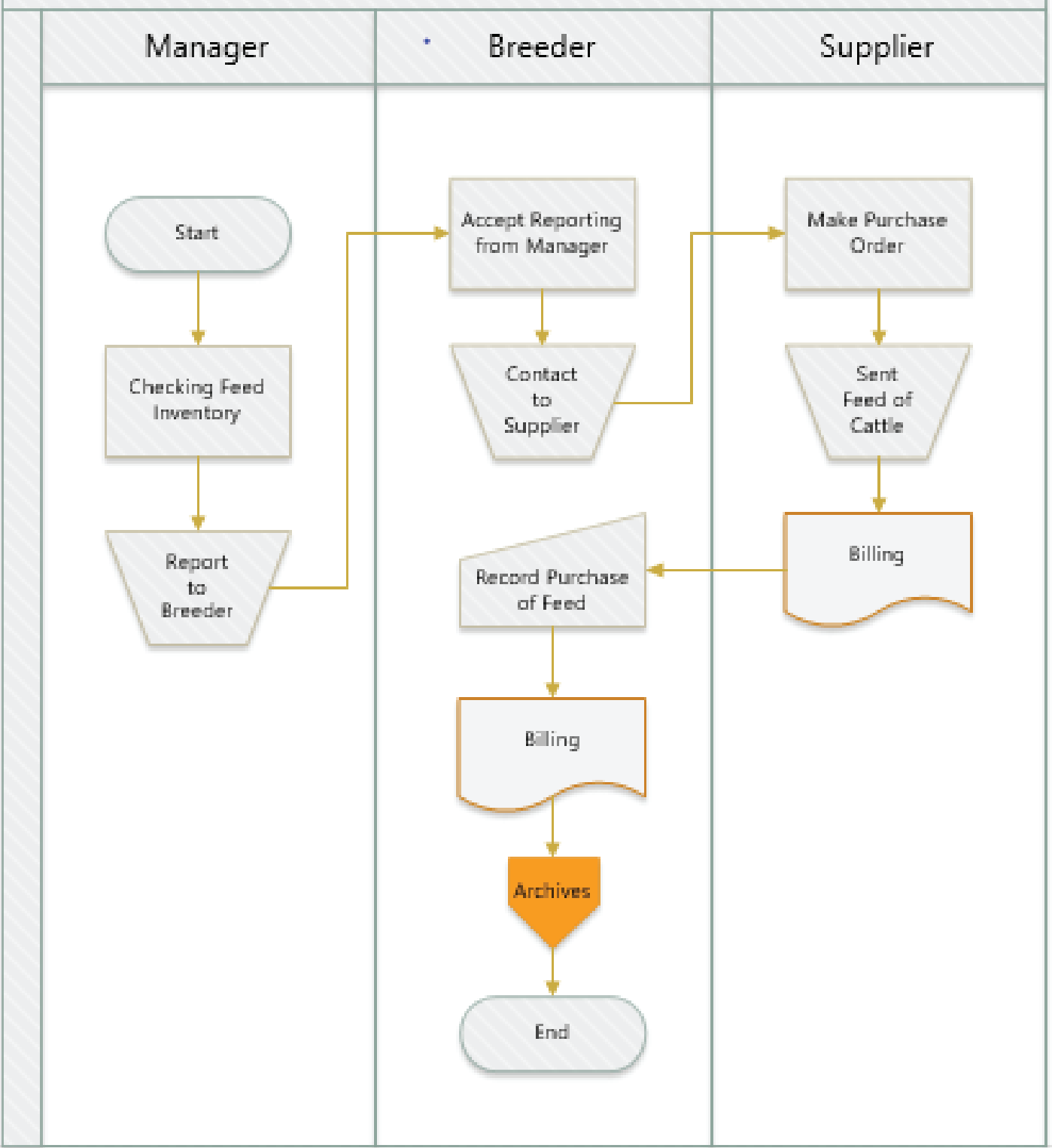

Figure 4: Flowchart of Feed Purchase Proposed.

The advantages of the proposed new system include:

1. Facilitate the breeder in making purchase order of feed to the suppliers.

2. Reduce documents that created manually in recording because the new system applies recording that utilize the database. In view of that, there will be no deserted or missing data to record.

3. The order can be done anytime and easier as it uses additional facility of e-mail. Thus, the documents of goods ordered are automatically saved to the computer. 
4. Purchase order data stored neatly and the storage does not require physical documents because the system has back up data.

5. Allow the breeder to collect more data of diverse suppliers to supplement feedstock requirements.

6. Facilitate the internal control of feed stock and milk sales data so that the deviation of data can be lessened.

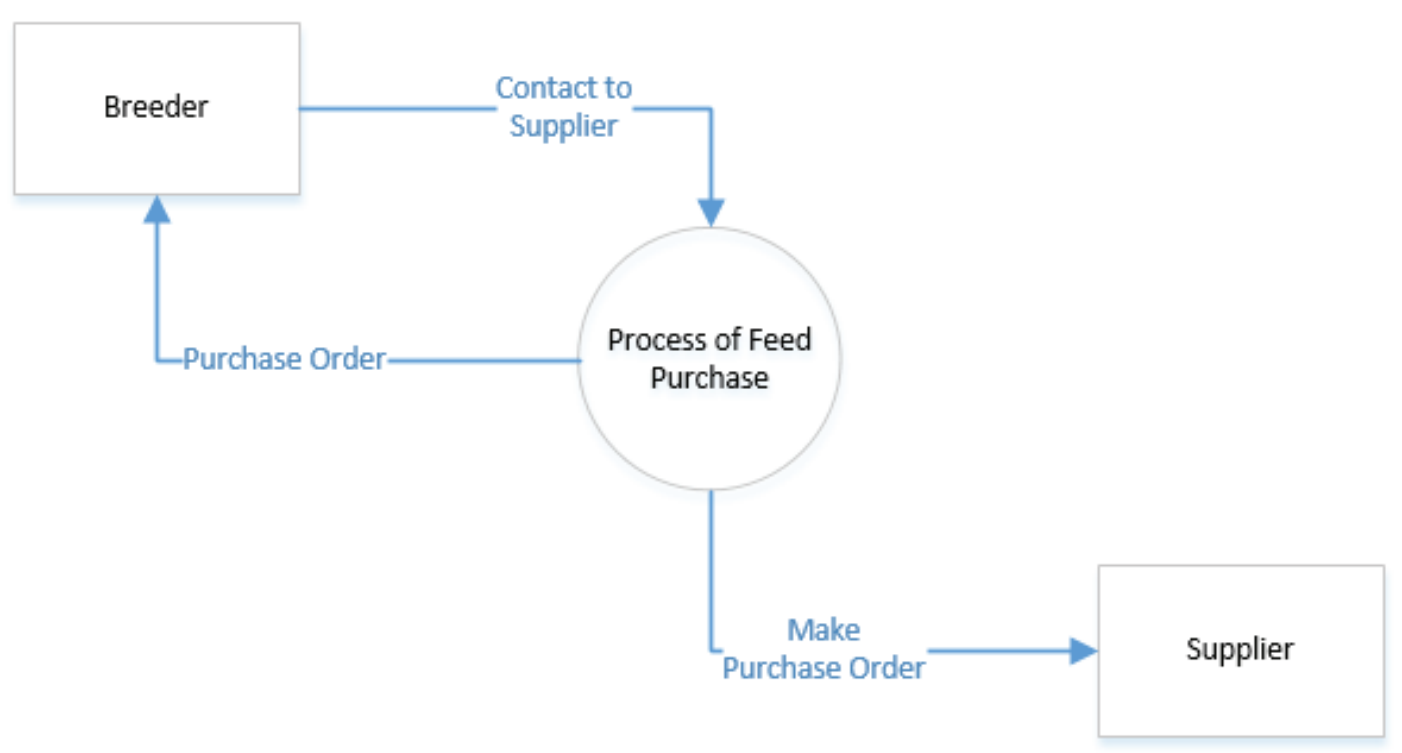

Figure 5: Context Diagram of Feed Purchase Proposed.

A top-level Context Diagram or DFD is the simplest diagram which does not describe the system in detail but generally describes the inventory purchasing system and gives a brief outlook of the external parties' data flow to the data and (internal) transaction processing until the output can be generated.

\subsection{Analysis of manufacturing information system need}

There are three input subsystems accompanied by four output subsystems in this research. The output subsystems are production, inventory subsystem, quality subsystem and cost subsystem. Here is an explanation of each input subsystem, database, and output subsystem. 


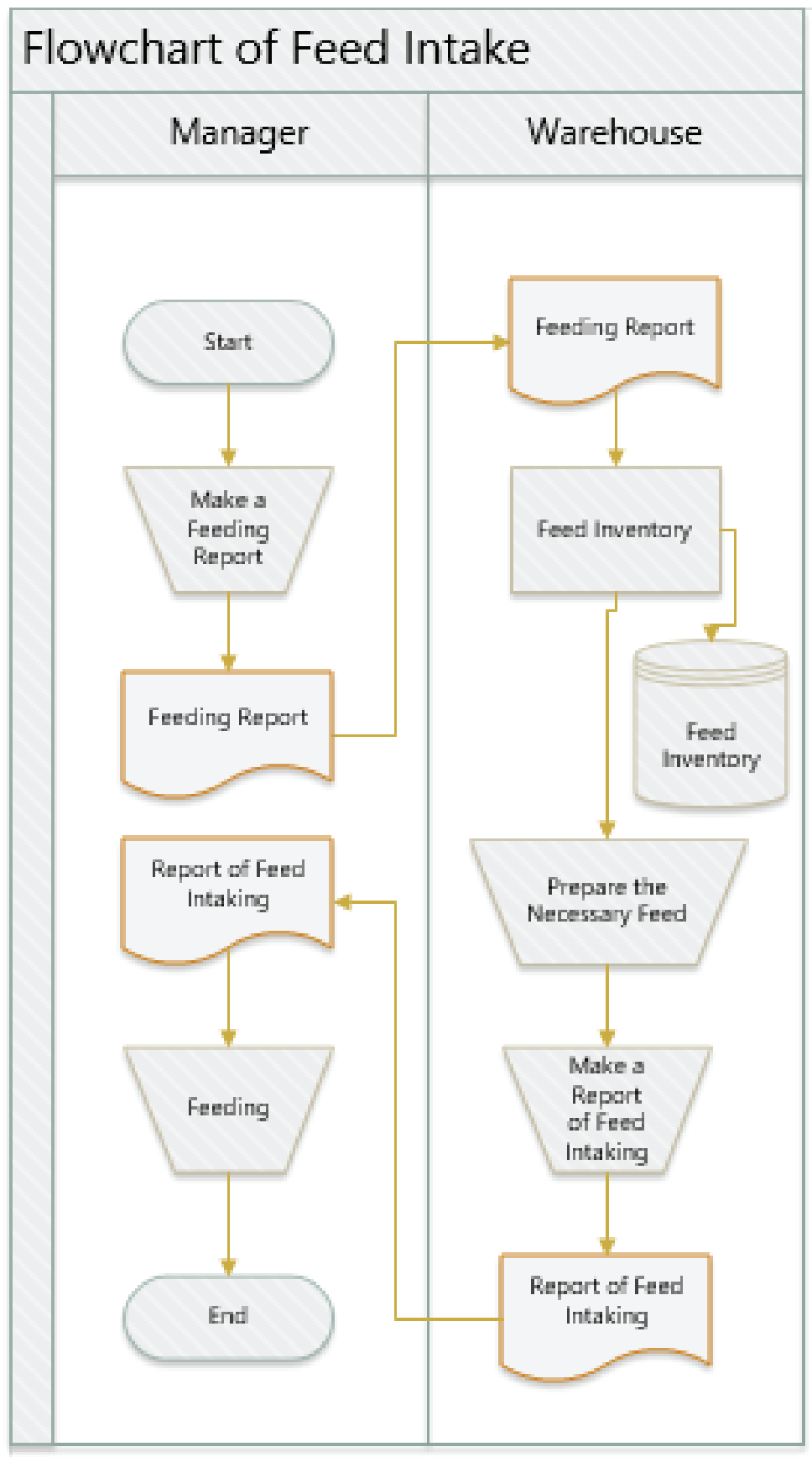

Figure 6: Flowchart of Feed Intake Proposed. 


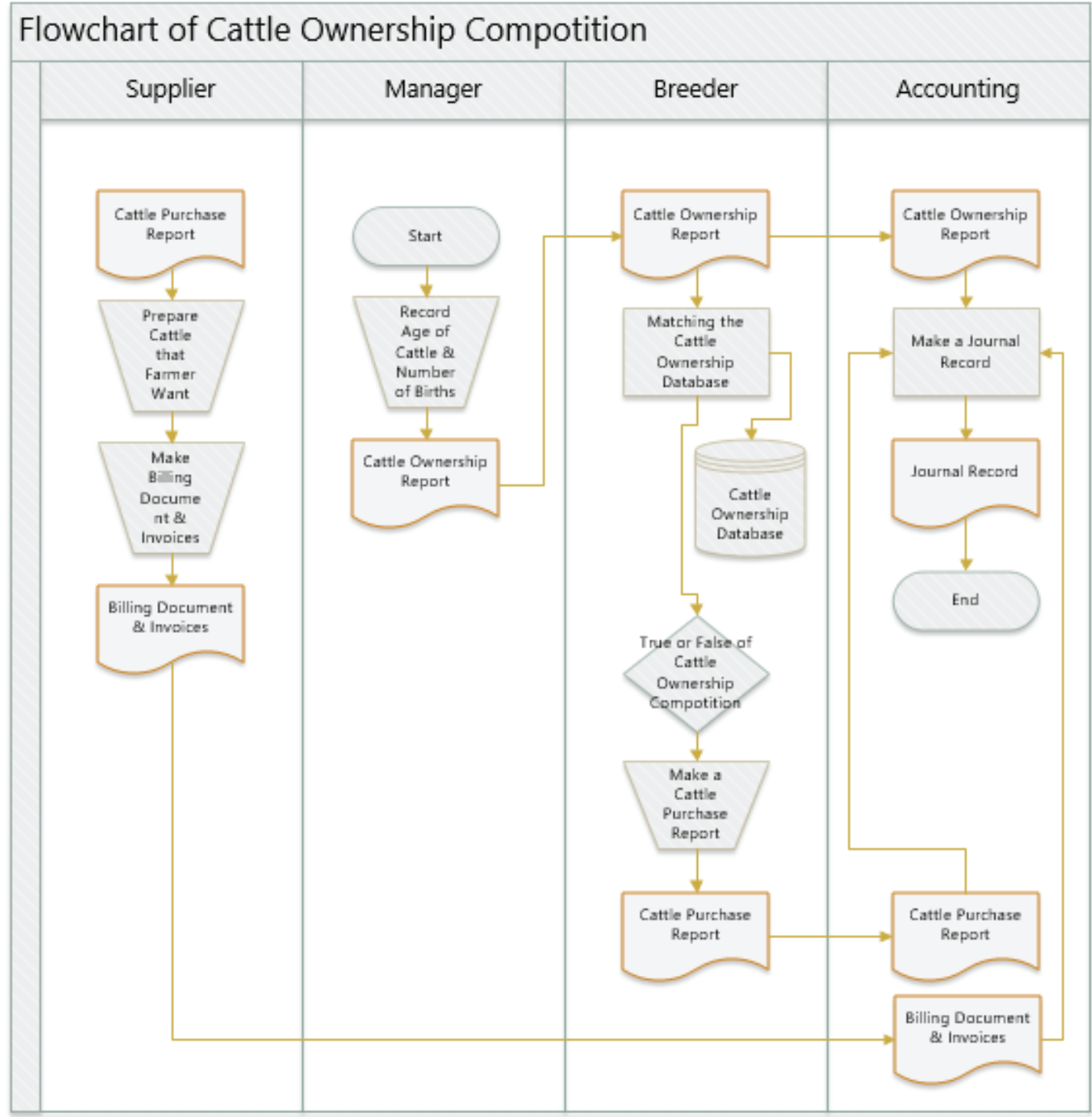

Figure 7: Flowchart of Cattle Ownership Compotition. 


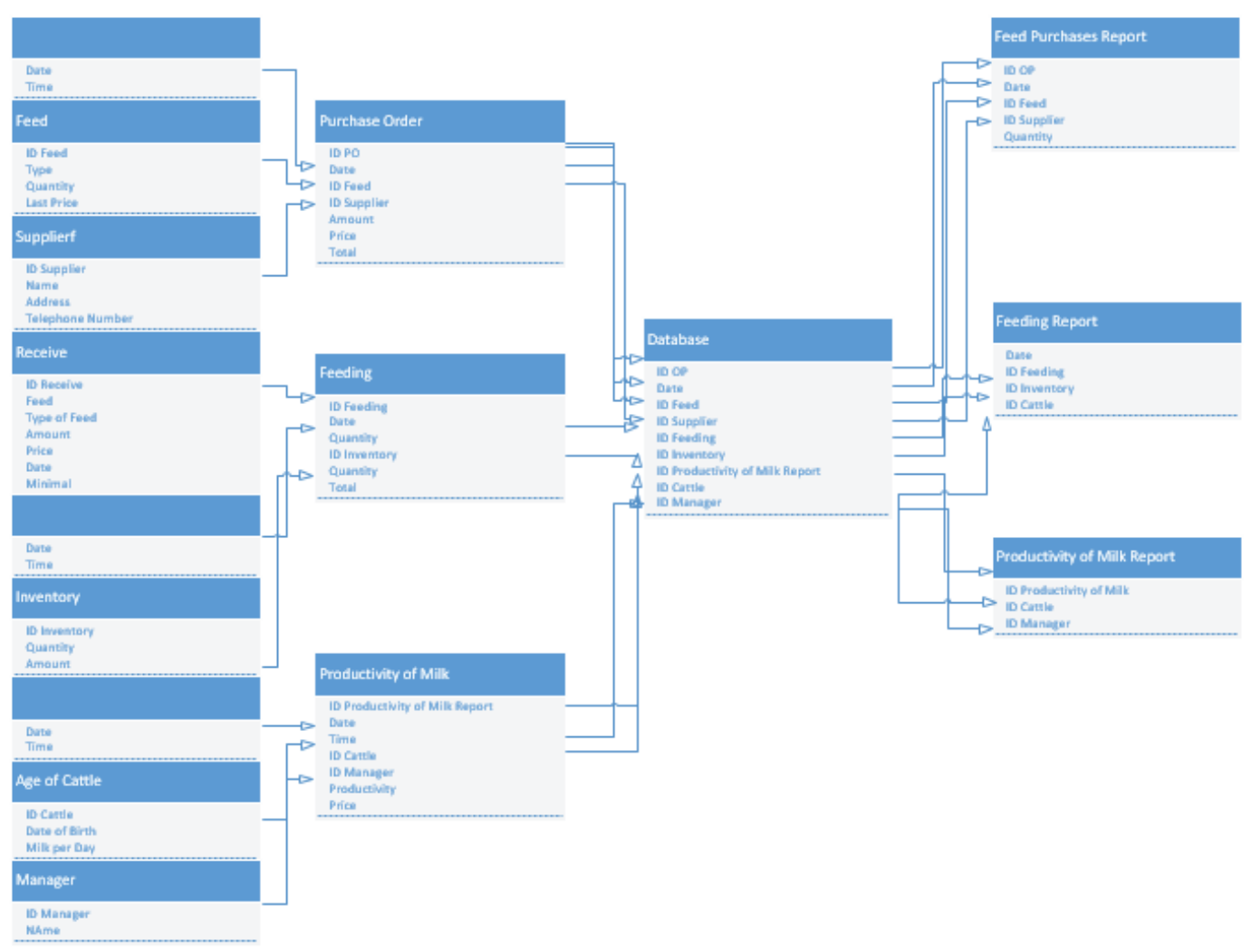

Figure 8: Entity Relationship Diagram of Feed Cattle.

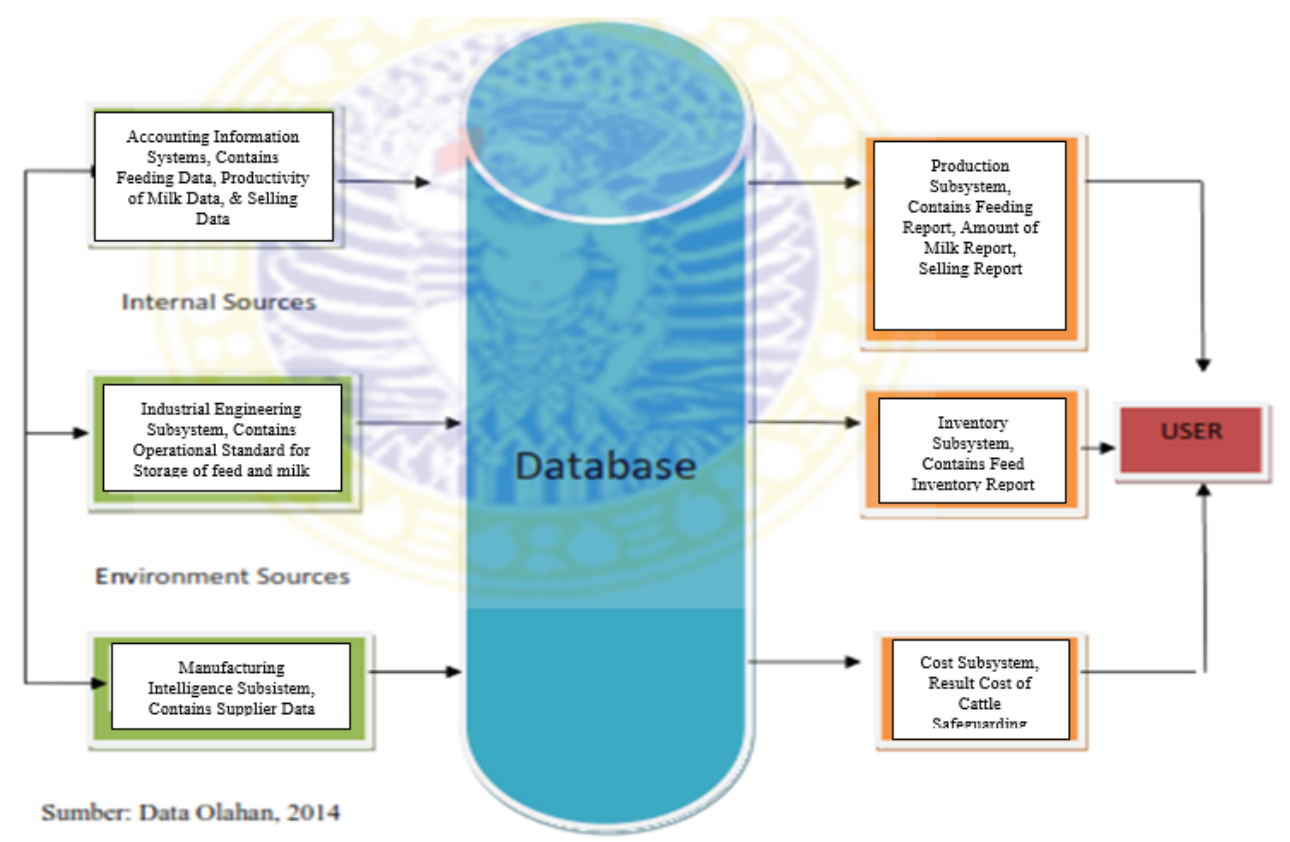




\subsection{Cost and benefit analysis}

The most imperative approach to decide between the choices to exercise the new system or maintain the old system is by calculating the amount of feed consumed each month, the milk produced each month, and the difference in the selling price of milk with the cost of feed each month. Likewise, the composition of cattle ownership factor is exceptionally influential to the profits earned by the farmer. The cattle composition recommended by the Animal Husbandry Department is: Calves (20\%), Heifers (20\%), Productive cows (40\%), and Dry/Pregnant Cows (20\%). All of these factors are useful for the breeder to generate maximum profit of $\mathrm{Rp} 7,500,000$ per month approximately. Below are some tables showing how the use of the new system will be able to benefit the farmer.

TABLE 2: The Difference Between the Milk Selling Price and the Feed Cost (January-April 2014).

$\begin{array}{lccc}\text { Month } & \text { Feed Cost Everyday } & \begin{array}{c}\text { Milk Selling Price } \\ \text { Everyday }\end{array} & \begin{array}{c}\text { Difference Between The Milk } \\ \text { Selling Price And The Feed Cost } \\ \text { Everyday }\end{array} \\ \text { January } & \mathrm{Rp} 983.980 & \mathrm{Rp} 1.305 .000 & \mathrm{Rp} 321.000 \\ \text { February } & \mathrm{Rp} 1.005 .220 & \mathrm{Rp} 1.381 .500 & \mathrm{Rp} 376.280 \\ \text { March } & \mathrm{Rp} 1.060 .000 & \mathrm{Rp} 1.489 .500 & \mathrm{Rp} 429.480 \\ \text { April } & \mathrm{Rp} 1.028 .760 & \mathrm{Rp} 1.566 .500 & \mathrm{Rp} 537.240\end{array}$

In table 2 , it can be seen that the difference between the milk selling price and the feed cost every day from January 2014 to April 2014 has increased. This indicates that the new system is very useful for the breeder in increasing the profit. To be noted, the daily cost of the feed in every month is increasing as the number of the cattle is also increasing. In January, there are 31 cows in the ranch and increasing to 37 cattle in April.

TABLE 3: The current composition of the cattle owners.

\begin{tabular}{|l|c|c|c|c|}
\hline Type of Cattle & January & February & March & April \\
\hline Calves & $16.1 \%$ & $18.2 \%$ & $27.0 \%$ & $18.9 \%$ \\
\hline Heifers & $12.9 \%$ & $12.1 \%$ & $10.8 \%$ & $18.9 \%$ \\
\hline Productive Cow & $48.3 \%$ & $51.5 \%$ & $51.3 \%$ & $43.2 \%$ \\
\hline Dry Cattle & $22.5 \%$ & $18.2 \%$ & $10.8 \%$ & $18.9 \%$ \\
\hline
\end{tabular}

Table 4.23 shows the composition of cattle ownership is nearing perfect (20\% of Calves, $20 \%$ of Heifers, $40 \%$ of Productive Cows, and $20 \%$ of Dry Cattle) referring how the new system can also help the breeder to have perfect cattle composition. The composition of cattle ownership is highly needed for farmers because if the composition of cattle ownership is perfect, the regeneration of the cattle can proceed well. That way, the farmers will not need to incur additional costs to buy new calves. 
TABLE 4: Milk Productivity per Day (January-April 2014).

\begin{tabular}{|l|c|}
\hline Month & Milk Productivity (Liter) \\
\hline January & 290 \\
\hline February & 307 \\
\hline March & 311 \\
\hline April & 348
\end{tabular}

Besides its function to help the farmer obtaining feed efficiency and perfect composition of cattle ownership, the new system is also able to help the farmer in improving the milk productivity. At the time before the new system is performed (January), the milk produced was only about 290 liters. While after the new system is applied (February, March, and April), the milk produced increased and reached 348 liters in April.

By this time, it can be concluded that applying the new system can increase milk productivity and efficient use of the feed hence the application of control system using manufacturing information system is highly recommended.

\section{Conclusions}

Based on the result of the analyses and discussions in the previous chapter, the conclusions of this study are:

1. The transactions recording in the cattle farm is still manually performed and done by employees (cage persons) who hardly have experience in inventory recording and financial statements preparation. This is why the recording that has been done is still not accurate.

2. The process of purchasing feed and milking milk between the owner of the farm and the employees (cage persons) are still using a trust based system and it indicates that there is an indication of irregularities.

3. The organizational structure of the dairy cattle farm of Mr. Djamil is still simple since it merely consists of the owner of the farm and the cage persons. In consequence, there are job combinations that performed (there is no clear division of job desks).

\subsection{Implication}

Implication in this study is: 
1. Currently, the dairy cattle farm has not applied the Manufacturing Information System in consuming the cattle feed and composing the cattle ownership. Feeding and composition of ownership that has been done has not been able to support the operational performance of the ranch in fulfilling the internal control concerns. Utilization of Manufacturing Information System is needed because without using the system, internal control can not run properly.

\subsection{Suggestions}

Taking the conclusions and implication into consideration, the suggestions that can be given through this research are as follows:

1. The management system of feeding and the composition of cattle ownership can not done simply through estimation. Thus, it is advisable to the cattle farm of Mr. Djamil to record transactions using the Manufacturing Information System since the ranch needs a computerized system for processing data from inputs to outputs in the form of feed purchase report, cattle ownership report, feeding report, and milk production per day report.

2. Further research is expected to be conducted for a more in-depth discussion regarding cost and benefit.

\section{References}

[1] Bodnar, George H\& William S. Hopwood. 2012. Accounting Information System Eleventh Edition. New Jersey: Prentice Hall.

[2] Gelinas, Ulric J \& Richard B. Dull. 2012. Accounting Information System Ninth Edition. Mason: Tomson Higher Education.

[3] Hall, James.2013. Accounting Information System Eighth. Mason : Cengage Learning. International Accounting Standard Boards (IASB). International Accounting Standard 41 Agriculture (Online), (http://icaew.com/en/library/subject-gateaway/ accountingstandart/IFRS/ias-41), diakses 14 Februari 2014.

[4] Indriani, Rully. 2014. Desain Sistem Informasi Pemasaran untuk meminimalisir kecurangan mitra bisnis pada CV. Mr. Jac Indonesia. Surabaya:UNAIR.

[5] Krismiaji. 2010. Sistem Informasi Akuntansi Edisi Tiga. Yogyakarta: UPP STIN YKPN. 
[6] Laudon Kenneth C. \& Jane. Laudon. 2007. Sistem Informasi Manajemen Buku Satu edisi sepuluh. Terjemahan oleh Chriswan Sungkono dan Mach Muden Eka P. 2007. Jakarta: Salemba Empat.

[7] McLeod, Raymond Jr \& George Schell. 2012. Management Information System Tenth Edition. New Jersey: Prentice Hall

[8] Novery, Ayu. 2013. Analisis Perencanaan Sistem Informasi Persediaan untuk menghasilkan laporan persediaan dan biaya pengelolaan berdasarkan IAS 41 dan PSAK 14 (Studi kasus pada rumah makan dan kolam pancing Agung, Pacet, Mojokerto). Surabaya: Universtas Airlangga.

[9] Tan Alice. 2013. How to value biological Assets. Singapura.

[10] Whitten, Jeffrey L., Et al. 2007. System Analysis Design Method Seventh Edition. New York: McGraw Hill Companies 